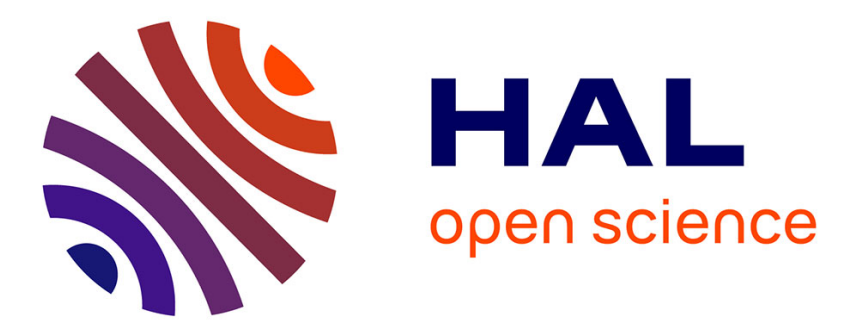

\title{
Influence of reprocessing on the properties of advanced polymers
}

J. Nazábal Echeberría

\section{To cite this version:}

J. Nazábal Echeberría. Influence of reprocessing on the properties of advanced polymers. Journal de Physique IV Proceedings, 1993, 03 (C7), pp.C7-1535-C7-1536. 10.1051/jp4:19937239 . jpa-00251876

\section{HAL Id: jpa-00251876 https://hal.science/jpa-00251876}

Submitted on 1 Jan 1993

HAL is a multi-disciplinary open access archive for the deposit and dissemination of scientific research documents, whether they are published or not. The documents may come from teaching and research institutions in France or abroad, or from public or private research centers.
L'archive ouverte pluridisciplinaire HAL, est destinée au dépôt et à la diffusion de documents scientifiques de niveau recherche, publiés ou non, émanant des établissements d'enseignement et de recherche français ou étrangers, des laboratoires publics ou privés. 


\title{
Influence of reprocessing on the properties of advanced polymers
}

\author{
J. NAZÁBAL ECHEBERRÍA
}

Polymer Science and Technology Department, University of Basque Country, 20080 San Sebastián, Spain

\begin{abstract}
In the manufacture of injection molded parts from thermoplastic polymers, large quantities of material are usually wasted on scrap material and faulty parts. The recuperation of such materials for reprocessing is justified from an economic point of view, especially considering the high price of the engineering thermoplastic used nowadays. Unfortunately, these high performance polymers require high temperatures for processing, so they may more easily undergo degradation processes that negatively affect properties. This fact complicates the re-use of scrap material. Thus, it is of great interest to study how reprocessing affects properties and how many processing cycles a material can bear and still demostrate acceptable performance.

The commercial importance of advanced polymers has clearly increased in recent years. This is mainly due to the high-temperature resistence of these polymers that is a consequence of their high $T_{g}$ or $\mathrm{T}_{\mathrm{m}}$. Moreover, they usually show exceptional toughness, strength and rigidity, among other important properties.

The above-mentioned facts explain why in this work we have studied the effects of harsh processing conditions like reprocessing, on the properties of several advanced commercial polymers. These polymers are poly(ether sulfone) (PES), poly (ether ketone) (PEEK) and a commercial polysulfone/polycarbonate blend (Mindel).

All the materials have been repeatedly injection molded. After each injection moulding cycle specimens were taken out for analysis and testing. In the case of PEEK related work was also carried out by kneading in a Brabender Plasticorder. Kneading allows for a direct contact of PEEK with the surrounding air. This procedure signifies a clear option to be produced, besides mechanical degradation, chemical reactions such as oxidation.

In the case of PES up to five injection cycles were carried out at $360^{\circ} \mathrm{C}$. The possibility of degradation by crosslinking was neglected by
\end{abstract}


means of FTIR analysis. A decrease in the molecular weight of the polymer was, however, detected by viscosimetry. This decrease in molecular weight gave rise to a decrease in the MFI of the material but did not produce any significative change in the most important mechanical properties of the polymer.

The study of the PEEk behaviour under harsh processing conditions, besides reprocessing by injection moulding, was made by kneading up to one our at $370^{\circ} \mathrm{C}$. The plot of torque of blending against time showed an increase of the torque with time. This indicated the occurrence of cross-linking or grafting reactions. The full solubility of PEEK in sulfuric acid proved the basic grafting nature of the reaction. The extent of this reaction must be, however, low because of its negligible effect on the crystallinity level of the material and as a consecuence on the mechanical properties of the polymer.

The reprocessing of PEEK by injection moulding at 370 and $390^{\circ} \mathrm{C}$ gave rise to an increase in the MFI of PEEK more important when injection moulding was carried out at $390^{\circ} \mathrm{C}$. This change in MFI had not relevant influence on the crystalline content of PEEK and only a small influence on the mechanical properties of the material even after injection molding at $390^{\circ} \mathrm{C}$.

Finally, the effect of reprocessing on Mindel was also carried out by injection molding. All the high strain properties, mainly ductility, significantly decreased after five cycles at $320^{\circ} \mathrm{C}$. The results on FTIR, dynamic mechanical analysis, MFI and mechanical properties indicated that the presence of the two polymers together gives rise to the lack of maintenance of the properties of the polymers on the blend. Degradation under the stated conditions is mainly thermal and does not change the chemical nature of the blends. The low temperature secondary transitions of both PC and PSU were shifted to higher temperatures. The measured mechanical properties did not seem to agree with these changes in DMTA measurement. This probably means that the fine and difficult-to-observe structure of the blend has also changed. 